\title{
Quality Measurement Evaluation of the POLSRI Learning Management System Website Using Importance Performance Analysis (IPA) Method
}

\author{
Irma Salamah ${ }^{1, *}$ Lindawati $^{1}$ Asriyadi $^{1}$ M.Fadhli ${ }^{1}$
}

\author{
${ }^{1}$ Telecommunication Program Study, State Polytechnic of Sriwijaya \\ *Corresponding author. Email: irma_salamah@polsri.ac.id,
}

\begin{abstract}
Technological advances have had an impact on all aspects of human life, one of which is the business world as well as the internet. A website is a means of providing information, promotion and communication to customers. This research tries to analyze the service quality of the POLSRI Learning Management System website with the aim of knowing the difference between the actual perceptions and ideal expectations of website users, in this case the POLSRI students. This research uses descriptive quantitative research methods. The analysis technique use Importance Performance Analysis (IPA). The results are 4 attributes that are top priority and need immediate improvements to improve service quality on the LMS POLSRI website, namely the ease of interacting clearly on the website, the website has an attractive appearance, the website creates a positive experience for user, and the level high trust in the information conveyed.
\end{abstract}

Keywords: Webqual, IPA, Learning Management System

\section{INTRODUCTION}

The 21st century has made the internet the main communication center in society. In developing countries in particular, the use of Information and Communication Technology (ICT) for human resource development has become widespread and is an important factor in developing a knowledge-based economy. ICTs have become the driving force that transforms business, economy, socio-political change, and commercial activity in a world without borders. These changes have affected the education sector completely over the last few years. The advent of information technology (IT) and the growing popularity of the World Wide Web have contributed to the rise of online learning [1].

Education is often dominated by the fact that the learning process must be done face-to-face. This information technology will continue to impact directly and indirectly on higher education to change traditional learning methods. Traditional learning interactions use a face-to-face approach while mixed mode combines face-to-face with online components. E-learning emphasizes the use of ICT tools for face-to-face online interactions [2].
The rapid development of ICTs, particularly internet technology, has created new opportunities for education. E-learning has great potential to enable higher education institutions to improve learning and teaching, increase access to resources and teaching programs, expand learning opportunities through online learning, and reduce education costs in the long term. However, it has some limitations such as a lack of faceto-face interaction with instructors and classmates, high initial costs to prepare online courses, large costs for updating and maintaining systems, and the need for flexible teaching support. Blended learning has been offered as a lucrative alternative learning approach [3].

One part of E-Learning is known as the Learning Management System (LMS). LMS has become an important tool for stakeholders in education and training. The importance of LMS is not limited to effectiveness and efficiency in teaching in higher education institutions but it further promotes knowledge sharing in an effective and efficient manne [1]. Learning Management System (LMS) in higher education serves to regulate the management of learning in the e-learning model. To make it clearer that the LMS (Learning Management System) is a software for administrative 
purposes, documentation, material search, activity reports. Currently, many universities use LMS for administrative purposes, documentation, activity reporting, implementation of learning activities, and implementation of online exams. This Learning Management System contains materials in educational and professional competencies which are made in multimedia packaging (text, animation, video, sound) and are provided as supplements and enrichments for the development of learner competencies. The presence of LMS brings better hope from the current education system, namely face-to-face meetings between students and lecturers, which still leaves some problems in the teaching and learning process [4].

Importance Performance Analysis (IPA) is a method for measuring user satisfaction with a product or service offered. The approach is based on the importance and performance of the existing products or services. The results of the analysis using this method will be divided into Cartesian diagrams with 4 quadrants, namely quadrant A (concentrate here), quadrant B (keep up the good work), quadrant C (low priority), and quadrant D (possible overkill). The $\mathrm{x}$-axis on the diagram represents the level of performance and the $y$-axis represents the level of importance [5].

State Polytechnic of Sriwijaya (POLSRI) optimizes the use of information technology to support learning activities manifested through the development of an integrated ICT-based learning system. The ICT-based learning system allows lecturers to manage content while carrying out learning management functions more easily and flexibly. Since 2016 State Polytechnic of Sriwijaya (POLSRI) has implemented an LMS to support learning called LMS POLSRI which can be accessed at http://lms.polsri.ac.id/login/index.php. LMS POLSRI has various facilities, including storage of teaching materials, distribution of teaching materials, posting announcements, posting assignments for students, conducting online tests / examinations, interactive dialogue (chatting) between teachers and learning participants. With the LMS POLSRI, lecturers can manage course material starting from compiling a syllabus, uploading material, giving assignments, receiving and responding to student work, making quizzes or tests, conducting assessments, monitoring student participation, and interacting with fellow lecturers and students both in forums scientific and online discussions. On the LMS POLSRI website, no one has ever conducted research on the analysis of service quality from the LMS POLSRI website, this makes management unable to know whether the LMS POLSRI website built is of good quality for its users. The problem that arises today is whether the LMS POLSRI website has good service quality for its users.

Based on the above problems, it is necessary to make an effort to evaluate the LMS POLSRI website by conducting the quality assessment analysis of website services from the user's side with the aim of knowing the difference between the actual perceptions and ideal expectations of website users, in this case the POLSRI students. This analysis use IPA analysis method. The results that will describe the quality of LMS POLSRI website services.

The benefit that can be obtained from this research is that it can provide material for consideration or input to the management who manages the LMS website about what actions management should take for the successful implementation State Polytechnic of Sriwijaya LMS website service.

\section{RESEARCH METHODS}

The population of this research is the active students State Polytechnic of Sriwijaya. Samples were taken from D4 students of telecommunications engineering and D4 students of informatics management, totaling 240 students. The questionnaire was given online and was given 1 month to fill in. After 1 month only 109 students filled out the questionnaire. So that the samples taken in this study were 109 respondents.

Model framework in this study can be seen in the image below:

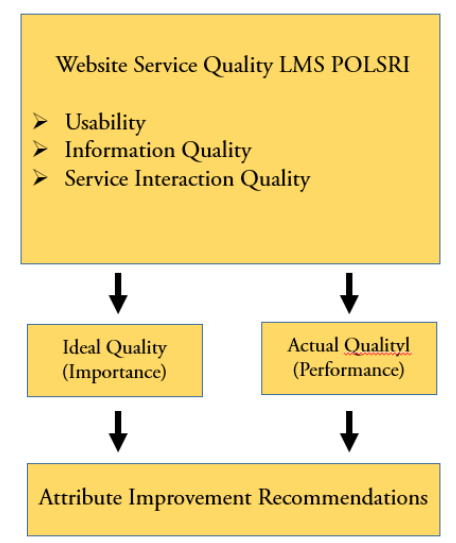

Figure 1. Research Model Framework IPA (Importance Performance Analysis) Methods

Importance Performance Analysis (IPA) is used to see which indicators of the quality of the website are in accordance with the wishes of the user and which ones need improvement. The results of the IPA analysis show the location of each indicator in the IPA matrix which consists of 4 (four) quadrants. Analysis of the importance and performance can produce a Cartesian diagram which can show the location of the factors or elements that are considered to influence customer satisfaction, where in the Cartesian diagram the factors will be described in four quadrants.

The Cartesian diagram consists of four quadrants [6]: Quadrant A (Concentrate Here)

This quadrant contains attributes / statements that are considered important by user but in reality these 
attributes / statements are not in accordance with customer expectations. The level of performance of the attribute / statement is lower than the level of customer expectations of the attribute / statement. The performance of the attributes / statements contained in this quadrant must be further improved in order to satisfy customers.

\section{Quadrant B (Keep Up The Good Work)}

Attributes / statements in this quadrant have high levels of expectation and performance. This shows that these attributes / statements are important and have high performance. And must be maintained for the next time because it is considered very important / expected and the results are very satisfying.

\section{Quadrant C (Low Priority)}

Attributes / statements in this quadrant are considered less important by customers and in fact their performance is not too special / ordinary. It means that the attributes / statements in this quadrant have a low level of importance / expectations and their performance is also considered poor by customers. Improvements to attributes / statements that are included in this quadrant need to be reconsidered by looking at attributes / statements that have an influence on the benefits felt by the customer large or small, and also to prevent these attributes / statements from shifting to quadrant A.

\section{Quadrant D (possible overkill)}

Attributes / statements in this quadrant have a low level of expectations according to customers but have good performance, so they are considered excessive by customers. This shows that the attributes / statements that affect customer satisfaction are overestimated in their implementation, this is because customers think they are not too important / less expected of these attributes / statements, but they are done very well.

\section{RESULTS AND DISCUSSION}

Table 4.5. Attribute average between $\mathrm{Xi}$ Dan $\mathrm{Yi}$ Website LMS POLSRI

\begin{tabular}{|c|c|c|}
\hline $\begin{array}{c}\text { Attribute } \\
\text { (Dimensi Webqual) }\end{array}$ & $\begin{array}{l}\text { Performance } \\
\mathrm{Xi}\end{array}$ & $\begin{array}{l}\text { Importance } \\
\mathrm{Yi}\end{array}$ \\
\hline \multicolumn{3}{|l|}{ Usability Quality } \\
\hline A1: Ease of learning to operate the website & 4.40 & 4.36 \\
\hline A2: Ease of interaction clearly on the website & 4.31 & 4.34 \\
\hline A3: Ease of navigation on the website & 4.18 & 4.20 \\
\hline A4: Website easy to use & 4.45 & 4.34 \\
\hline A5: The website has an attractive appearance & 4.18 & 4.31 \\
\hline A6: The website has a suitable type design & 4.23 & 4.26 \\
\hline $\begin{array}{l}\text { A7: The website creates a positive experience for } \\
\text { the user }\end{array}$ & 4.28 & 4.36 \\
\hline A8: The website has a competency & 4.18 & 4.27 \\
\hline \multicolumn{3}{|l|}{ Service Interaction Quality } \\
\hline A9: The website has a good interface & 4.04 & 4.12 \\
\hline $\begin{array}{l}\text { A10: Security in downloading materials, uploading } \\
\text { assignments, online examinations }\end{array}$ & 4.45 & 4.36 \\
\hline A11: The website has a good reputation & 4.41 & 4.47 \\
\hline A12: Security of User's personal information & 4.43 & 4.27 \\
\hline A13: Make room for personalization & 4.34 & 4.21 \\
\hline A14: Make room for community & 4.26 & 4.18 \\
\hline $\begin{array}{l}\text { A15: Ease of communicating with friends and } \\
\text { lecturers }\end{array}$ & 4.35 & 4.28 \\
\hline $\begin{array}{l}\text { A16: High level of confidence in the information } \\
\text { conveyed }\end{array}$ & 4.34 & 4.34 \\
\hline \multicolumn{3}{|l|}{ Information Quality } \\
\hline A17: The information presented is accurate & 4.45 & 4.40 \\
\hline A18: The information provided is reliable & 4.47 & 4.37 \\
\hline A19: Up to date information & 4.42 & 4.32 \\
\hline A20: Relevant information as desired & 4.34 & 4.31 \\
\hline A21: Information that is easy to understand & 4.53 & 4.36 \\
\hline A22: More detailed information & 4.45 & 4.42 \\
\hline A23: Information in an appropriate format & 4.37 & 3.97 \\
\hline
\end{tabular}

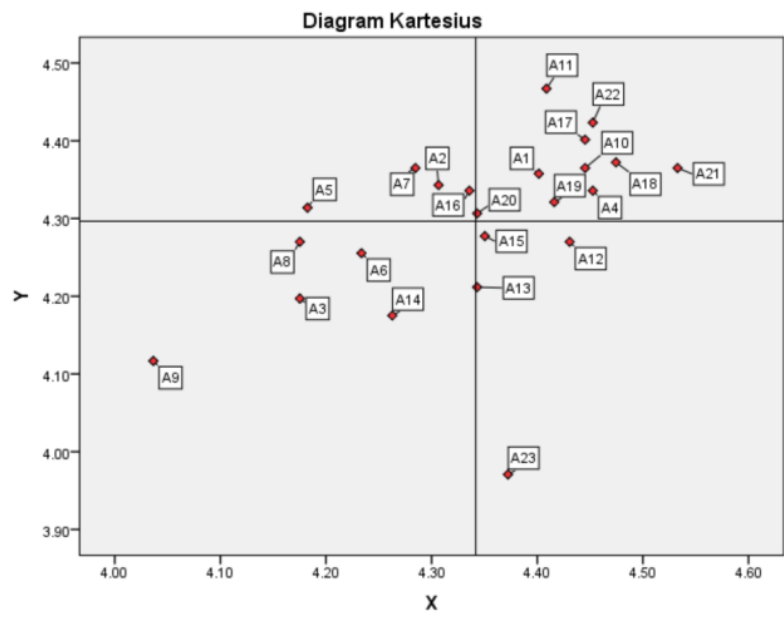

Figure 2. Cartesian Diagram

Based on Figure 2, it can be seen that the attributes that are in quadrant $\mathrm{A}$ are attributes that have a very low level of satisfaction (not satisfying users) according to the LMS POLSRI website users. This results in users feeling disappointed and dissatisfied with the LMS POLSRI website so that for POLSRI this attribute is a top priority that must be corrected immediately according to the user's wishes or interests. Attributes that are in quadrant B are the attributes most expected by users as perceived and are supporting factors that are considered very important and very satisfying to users so that POLSRI are obliged to maintain the performance or achievement of the attributes in this quadrant. Attributes that are in quadrant $\mathrm{C}$ are attributes that have a low priority for users because they are considered less important and less satisfying to users and are not too special, so POLSRI do not need to prioritize or pay more attention to these services. Attributes that are in quadrant $\mathrm{D}$ are attributes that are considered less important to users but have excessive performance so that POLSRI is better off allocating resources associated with these ttributes to other variables that have a higher priority level.

The main priority attributes that must be improved are: easy interaction with the website, the website has an attractive appearance, the website creates a positive user experience, and a high level of trust in the information conveyed.

\section{CONCLUSIONS}

User perceptions based on the results of the IPA analysis, there are 4 attributes that are top priority and need immediate improvements to improve service quality on the LMS POLSRI website, namely the ease of interacting clearly on the website, the website has an attractive appearance, the website creates a positive experience for the user, and the level high trust in the information conveyed, and 10 attributes that must be maintained because its performance is in accordance with user expectations, namely the ease of learning to 
operate the website, the website is easy to use, the security in downloading materials, uploading assignments, online examinations, the website has a good reputation, the information presented is accurate, the information provided is reliable, information is up to date, relevant information as desired, information that is easy to understand, information in more detail. Some of the attributes that can also be recommended to be improved to further improve the quality of LMS POLSRI website services to match user expectations are ease of navigation on the website, the website has a suitable type design, the website has a competency value, the website has an good interface, and make room for community.

\section{AUTHORS' CONTRIBUTIONS}

The contribution of the research is provide recommendation attributes LMS Polsri that need to be improved.

\section{ACKNOWLEDGMENTS}

In accordance with the publishing of FIRST Proceeding, we would like to take this opportunity to thank you for polytechnic which has provided financial support for this research

\section{REFERENCES}

[1] S. Ghazal, H. Aldowah, I. Umar, and B. Bervell, "Acceptance and Satisfaction of Learning Management System Enabled Blended Learning Based on a Modified DeLone- McLean Information System Success Model," Int. J. Inf. Technol. Proj. Manag., vol. 9, no. 3, pp. 52-71, 2018.

[2] H. Aldowah, S. Ghaza, and B. Muniandy, "Issues and Challenges of using E-Learning in a Yemeni Public University," Indian J. Sci. Technol., vol. Vol 8(32), 2015.

[3] C. R. Graham, Blended Learning Systems: Definition, Current Trends, And Future Directions. San Francisco,: Pfeiffer Publishing., 2003.

[4] N. Agustina, "Model Keberhasilan Belajar Mahasiswa Menggunakan Learning Management System (Studi Kasus Mahasiswa Bina Sarana Informatika)," J. Evolusi, vol. 4, no. 2, 2016.

[5] J. A. Martilla, "Importance-Performance Analysis," J. Mark., 1977.

[6] J. Supranto, Pengukuran Tingkat Kepuasan Pelanggan Untuk Menaikkan Pangsa Pasar. Jakarta: PT Rineka Cipta, 2006. 